\title{
Assessment of the use of cryopreserved $x$ freeze-dried amniotic membrane (AM) for reconstruction of ocular surface in rabbit model
}

\author{
Avaliação do uso da membrana amniótica (MA) criopreservada x liofilizada na \\ reconstrução da superfície ocular em coelhos
}

\author{
Rodrigo Doyle Libera ${ }^{1}$ \\ Gustavo Barreto de Melo ${ }^{2}$ \\ Acácio de Souza Lima ${ }^{3}$ \\ Edna Freymüller Haapalainen ${ }^{4}$ \\ Priscila Cristovam ${ }^{5}$ \\ Jose Álvaro Pereira Gomes ${ }^{6}$
}

Trabalho realizado na Universidade Federal de São Paulo - UNIFESP - São Paulo (SP) - Brazil.

${ }^{1}$ MD Department of Ophthalmology Federal University of São Paulo - UNIFESP - São Paulo (SP) - Brazil.

${ }^{2} \mathrm{MD}$, Department of Ophthalmology, Federal University of São Paulo - UNIFESP - São Paulo (SP) - Brazil.

Department of Pharmacology, Federal University of São Paulo - UNIFESP - São Paulo (SP) - Brazil

${ }^{4} \mathrm{MD} \mathrm{PhD}$, Sector of Eletronic Microscopy, Federal University of São Paulo - UNIFESP - São Paulo (SP) Brazil.

${ }^{5}$ Department of Ophthalmology, Federal University of São Paulo - UNIFESP - São Paulo (SP) - Brazil.

${ }^{6} \mathrm{MD} \mathrm{PhD}$, Department of Ophthalmology, Federal University of São Paulo - UNIFESP - São Paulo (SP) Brazil.

Corresponding author: Rodrigo Doyle Libera. Department of Ophthalmology Federal University of São Paulo. Rua Botucatu, 820 - São Paulo (SP) CEP 04023-062

E-mail: rodrigo.doyle@superig.com.br

Recebido para publicação em 21.12.2007

Última versão recebida em 28.05.2008

Aprovação em 17.06.2008

Nota Editorial: Depois de concluída a análise do artigo sob sigilo editorial e com a anuência da Dra. Amélia Kamegasawa sobre a divulgação de seu nome como revisora, agradecemos sua participação neste processo.

There is not competing interests of any authors regarding this study.

\begin{tabular}{l} 
ABSTRACT \\
\hline Purpose: To determine the efficacy of freeze-dried amniotic membrane \\
(AM) for reconstruction of the ocular surface in rabbit eyes. Methods: The \\
sterilized, freeze-dried amniotic membrane (lyophilized or FD-AM) is a \\
preservative method that uses the drying by freezing process to maintain \\
the AM well preserved for a long time even at room temperature. This paper \\
is an experimental animal interventional study. One eye of each of 15 male \\
New Zealand rabbits (1.5 - 3.0 kg) had the central cornea marked with a 6.0 \\
mm trephine. The marked area was deepithelialized with a No.15 blade. The \\
denuded corneal surface was covered as follows: Group $1:$ cryopreserved \\
AM (n=6); Group 2: freeze-dried AM (n=6); and Group $3:$ not covered \\
(control group, n=3). The AM in group 1 and 2 and the periphery of the \\
denuded area in group 3 were secured with continuous $10-0$ nylon sutures. \\
The clinical evaluation was made by a blinded observer and graded on a \\
four-point scale (1= minimal, $4=$ marked) for conjunctival and ciliary \\
hyperemia, eyelid edema, corneal neovascularization, corneal opacity and \\
reepithelialization on postoperative (PO) days 1,7 and 30 . After PO day \\
30, the rabbits were euthanized and their corneas were sent for his- \\
topathological and ultrastructural analysis to evaluate tissue inflam- \\
mation, reepithelialization, and basement membrane integrity. Results: \\
Two eyes in group 2 had a corneal infection and were excluded from the \\
analysis. No statistically significant differences among the three groups \\
were found (p>0.05) regarding the clinical evaluation on $1{ }^{\text {st }}, 7^{\text {th }}$ and $30^{\text {th }}$ PO \\
days. On transmission electron microscopy, the basement membrane in \\
lyophilized and control groups was more continuous and homogeneous \\
than in the glycerol group. Conclusions: The freeze-drying method seems \\
to be a good option to preserve human amniotic membrane to be used in \\
ocular surface reconstruction. This preservative method reduces the \\
preservation costs and may enhance the use of AM, facilitating its storage \\
and transport.
\end{tabular}

Keywords: Amnion/transplantation; Freeze-drying; Cryopreservation; Tissue preservation/ methods; Rabbits

\section{INTRODUCTION}

Amniotic membrane (AM), the inner layer of the fetal membrane, consists of a double layer of epithelium, basement membrane and avascular stroma $^{(1)}$. In 1940, De Roth was the first to report on the use of amniotic membrane in Ophthalmology in the management of conjunctival defects ${ }^{(2)}$. In 1995, Kim and Tseng reintroduced the use of AM in an experimental 
model of limbal deficiency in rabbits, reporting that $77 \%$ of the experimental group improved corneal transparency and neovascularization $^{(3)}$.

Since then, many reports have supported the use of preserved human AM for ocular surface reconstruction due to its ability to reduce ocular surface inflammation and scarring and promote rapid reepithelialization ${ }^{(4-1)}$. These properties can be explained by the presence of growth factors, cytokines and metalloproteinases inhibitors ${ }^{(12-13)}$.

Ideally, for clinical use, AM should be sterile and free of contamination. It should also be easy to obtain, transport, and store for long periods without deterioration. However the most common preservation method, cryopreservation, requires an expensive and bulky $-80^{\circ} \mathrm{C}$ deep freezer to maintain the viability of $\mathrm{AM}$ for a long time; for instance, at $-4^{\circ} \mathrm{C}$, the $\mathrm{AM}$ has a storage time of about 1 month $^{(14)}$. These are limitations to the wider use of AM, particularly in developing countries.

Sterilization followed by lyophilization (freeze-drying) is a preservation method used to maintain the AM viable for a long time, even at room temperature. Reports have shown that the characteristics of AM are preserved by lyophilization ${ }^{(15)}$ and the use of this tissue gives good results in ocular surface reconstruction after pterygium surgery ${ }^{(16)}$. This method reduces preservation costs, facilitates storage and transport, and may encourage the use of AM in surgical procedures.

To the best of our knowledge, there are no previous reports comparing the use of freeze-dried AM with the cryopreserved AM in an animal model. The purpose of the study is to determine the efficacy of freeze-dried AM, comparing with cryopreserved AM in ocular surface reconstruction in rabbits.

\section{METHODS}

This paper is an experimental interventional animal study. All animals were treated in agreement with the ARVO statement for the use of animals in ophthalmic and vision research. With proper informed consent and in accordance with the tenets of the Declaration of Helsinki for research involving human subjects, human AMs were obtained at the time of elective cesarean section at the Amparo Maternal Hospital, São Paulo, Brazil from volunteers who were seronegative for human immunodeficiency virus, hepatitis B and C and syphilis. This study was approved by the Research Ethics Committee (CEP) of the Federal University of São Paulo (UNIFESP/EPM), Brazil.

\section{Preparation of Amniotic Membrane}

Under sterile conditions, the placenta was washed with $0.9 \%$ saline. The amnion was separated from the chorion with sterile instruments and was flattened epithelium side up on a sterile nitrocellulose filter (Millipore, Bedford, MA, USA). The $\mathrm{AM}$ and filter were washed with sterile phosphate-buffered saline (PBS) containing $1000 \mathrm{U} / \mathrm{mL}$ penicillin, $20 \mu \mathrm{g} / \mathrm{mL}$ streptomycin and $2.5 \mu \mathrm{g} / \mathrm{mL}$ amphotericin B (Ophthalmos, São Paulo, Brazil), and cut into approximately $3 \times 3 \mathrm{~cm}$ pieces.
Amniotic epithelial cells were removed by incubation with $0.02 \%$ ethylene-diaminetetraacetic acid. Fifty percent of the AM denuded fragments were cryopreserved in DMEM-glycerol (1:1) solution (Ophthalmos, São Paulo Brazil) and frozen at $-80^{\circ} \mathrm{C}$. The other fifty percent were freeze-dried under vacuum and vacuumpacked at room temperature using a Thermo Savant freeze-dryer (Boc Group Inc., New Jersey, USA). Microbiological tests were performed on the membranes to confirm sterilization.

\section{Surgical Technique}

One eye of each of 15 male New Zealand rabbits $(1.5-3.0 \mathrm{~kg})$ had the central cornea marked with a $6.0 \mathrm{~mm}$ trephine under topical anesthesia with $0.5 \%$ proparacaine hydrochloride solution and systemic anesthesia with xylazine $(1.1 \mathrm{mg} / \mathrm{kg})$ and ketamine hydrochloride $(6 \mathrm{mg} / \mathrm{kg})$. The marked area was deepithelialized with a No. 15 blade. The denuded corneal surface was covered as follows: Group 1: cryopreserved AM ( $\mathrm{n}=6)$; Group 2: freeze-dried AM ( $\mathrm{n}=6)$; and Group 3: not covered (control group, $\mathrm{n}=3$ ). The AM in group 1 and 2 and the periphery of the denuded area in group 3 were secured with continuous 10-0 nylon sutures.

\section{Clinical and Statistical Analysis}

The clinical evaluation was made by a blinded observer and graded on a four-point scale ( $1=$ minimal, $4=$ marked $)$ for conjunctival and ciliary hyperemia, eyelid edema, corneal neovascularization (1-4 for extension and 1-4 for depth), corneal opacity and reepithelialization on postoperative (PO) days 1, 7 and $30^{(17)}$. After PO day 30, the rabbits were euthanized and their corneas were sent for histopathological and ultrastructural analysis to evaluate tissue inflammation, reepithelialization, and basement membrane integrity. Statistical analysis was performed with the Mann-Whitney test for comparison between groups.

\section{Histopathological and Ultrastructural Analysis}

Histopathological analysis was performed on slides stained with hematoxylin-eosin (H\&E) and observed under a light microscope. For transmission electron microscopy (TEM), specimens were fixed in $2.0 \%$ glutaraldehyde in $0.1 \mathrm{M}$ sodium cacodylate solution, washed three times for 15 minutes each in $0.1 \mathrm{M}$ sodium cacodylate solution, and postfixed for 2 hours in $2 \%$ osmium tetroxide solution. The specimens were washed two more times in $0.1 \mathrm{M}$ sodium cacodylate solution before being passed through a graded ethanol series (70, 90 and 100\%). For TEM preparation, the specimens were embedded in propylene oxide-epoxy resin $(2: 1$; $1: 1 ; 1: 2$ and 1:3). Ultrathin $(70 \mathrm{~nm})$ sections were collected on copper grids and stained for 1 hour with uranyl acetate and lead citrate before examination on a Jeol Jem 1200 EX II TEM.

\section{RESULTS}

Both freeze-dried and cryopreserved AMs could be easily handled and sutured to the corneal bed. The elasticity of the freeze-dried AM increased with hydration. Postoperatively, all transplanted AMs maintained their graft integrity and were well retained (Figure 1). 
Two eyes in group 2 with corneal infection were excluded from the analysis. No statistically significant differences were found $(p>0.05)$ between the three groups regarding the clinical evaluation (conjunctival and ciliary hyperemia, eyelid edema, corneal neovascularization, corneal opacity and reepithelialization) performed at PO days 1,7 and 30 (Tables 1 and 2).

Histological analysis showed that the structural integrity of the cornea was well preserved in all groups. The inflammation (cellularity) seems to be more intense in Group 1 (Figure 1).

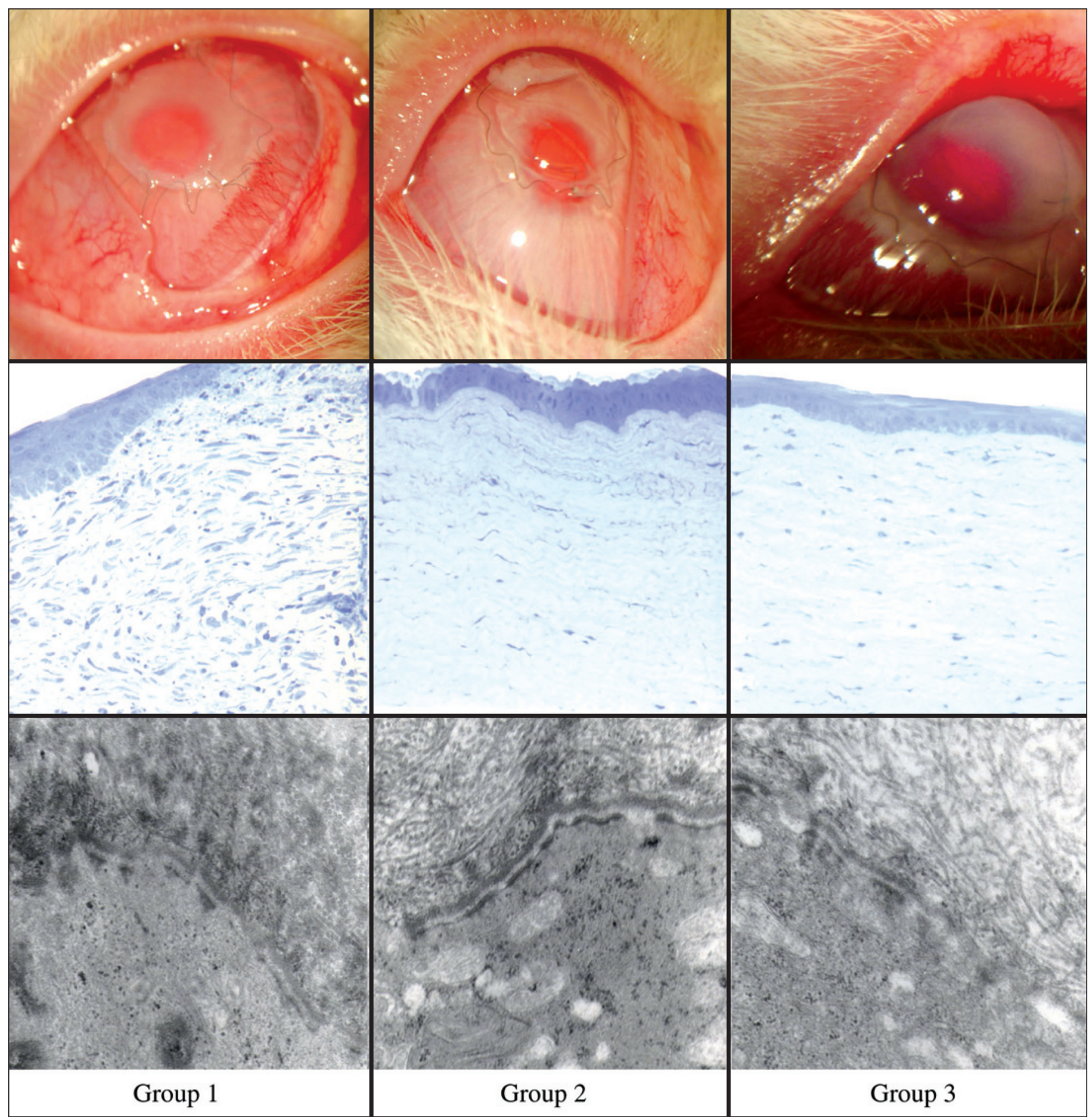

Figure 1 - Comparison of the groups regarding clinical, histological and ultrastructural aspects. The clinical aspect is similar in both experimental groups. The histological analysis shows a good preservation of the corneal structure and epithelialization and the cellularity seems to be more intense

in Group 1. The transmission electronic microscopy analysis shows the good preservation of the basal membrane, principally in Group 2. 


\begin{tabular}{|c|c|c|c|c|}
\hline Variable & Median & SD & IQ interval & $p$ value \\
\hline \multicolumn{5}{|l|}{ Corneal opacity - 7d } \\
\hline Cryopreserved AM Group (1) & 1.0 & 0.51 & 1 & \\
\hline Freeze-dried AM Group (2) & 1.5 & 0.57 & 1 & \\
\hline Control Group (3) & 2.0 & 0.57 & 1 & \\
\hline \multicolumn{5}{|l|}{ Difference } \\
\hline$(1)(2)$ & 1.0 & & & 0.11 \\
\hline$(2)(3)$ & 0.5 & & & 0.85 \\
\hline \multicolumn{5}{|l|}{ Corneal neovascularization - $7 d$} \\
\hline Cryopreserved AM Group (1) & 4.5 & 1.26 & 2.25 & \\
\hline Freeze-dried AM Group (2) & 3.5 & 2.87 & 4.75 & \\
\hline Control Group (3) & 5.0 & 0.57 & 1.00 & \\
\hline \multicolumn{5}{|l|}{ Difference } \\
\hline$(1)(2)$ & 1.0 & & & 0.35 \\
\hline (2)(3) & 1.5 & & & 0.40 \\
\hline \multicolumn{5}{|l|}{ Corneal non epithelialization - 7d } \\
\hline Cryopreserved AM Group (1) & $52 \%$ & 41.68 & 81.25 & \\
\hline Freeze-dried AM Group (2) & $15 \%$ & 23.80 & 40.00 & \\
\hline Control Group (3) & $40 \%$ & 26.45 & 20.00 & \\
\hline \multicolumn{5}{|l|}{ Difference } \\
\hline$(1)(2)$ & 37.5 & & & 0.17 \\
\hline (2)(3) & 25.0 & & & 0.62 \\
\hline $\mathrm{SD}=$ standard deviation; $\mathrm{IQ}$ interval= int & & & & \\
\hline
\end{tabular}

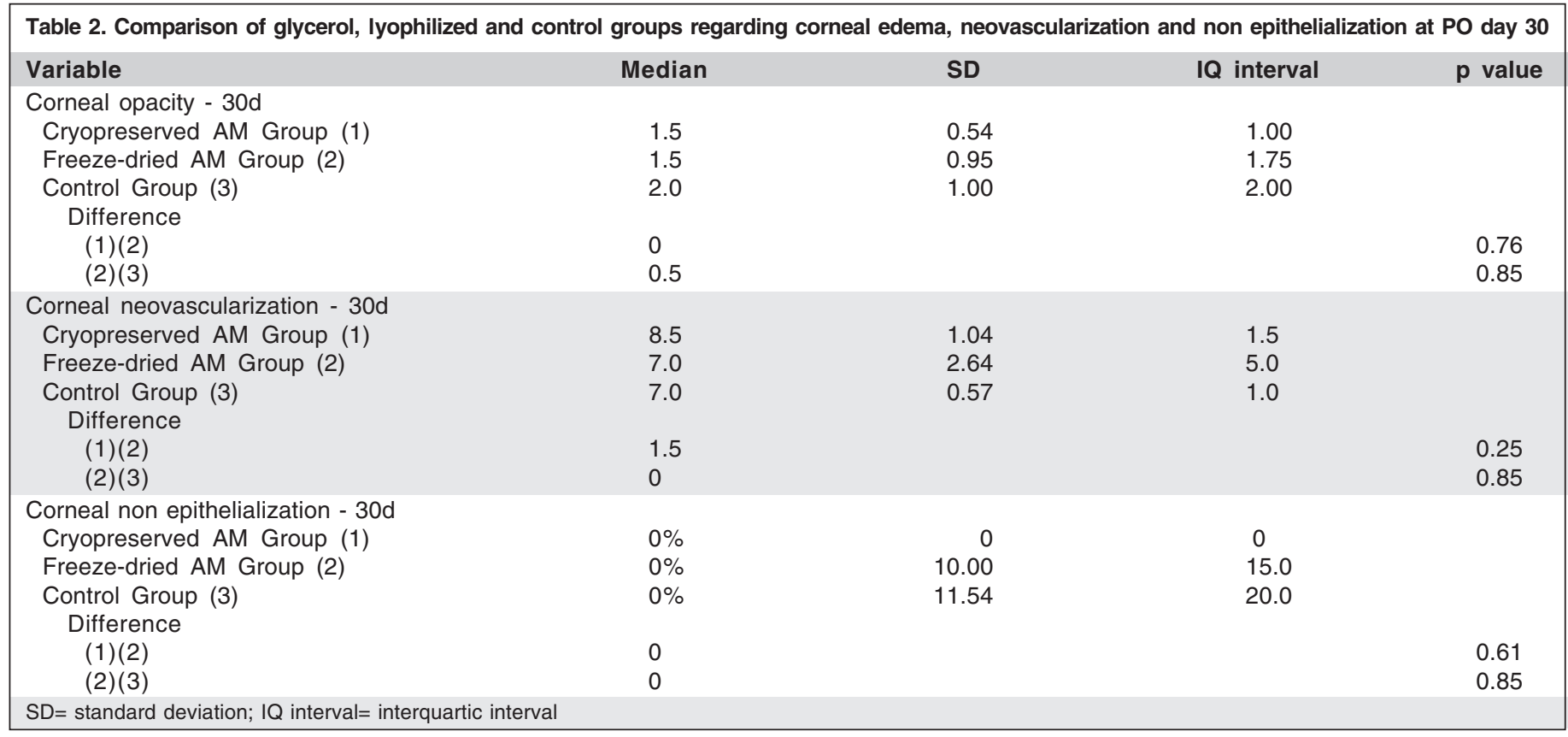

Ultrastructural analysis by TEM revealed that the amniotic basement membranes in Groups 2 and 3 were more continuous and homogeneous than in Group 1. The epithelium layer was well preserved in all groups (Figure 1).

\section{DISCUSSION}

Several methods have been used to preserve AM, including hypothermic storage and freezing. However, these me- thods require expensive and bulky equipments such as lowtemperature freezers. Therefore, it would be very convenient if AM could be kept at room temperature.

In this study, two eyes in Group 2 developed corneal infection. Probably the infection was not associated with the lyophilization itself, because the microscopic evaluation of the membranes, after they passed through the freeze-drying process, was negative. In this study, antibiotic prophylaxis was used only in the immediate postoperative period. There are antibiotics in the DMEM-glycerol solution and not in 
FD AM, this being the potential cause of infection only in Group 2.

The clinical results showed no differences between the three groups. For the control group, the results were better than expected probably because the corneal lesions were too superficial in our model. However, this method was previously used for treatment of bullous keratophathy with good results $^{(18-19)}$. Clinical evaluation between Groups 1 and 2 showed no statistically significant differences. This fact demonstrates that the type of preservation method used did not affect the clinical properties of the AM in our model.

Similar results were obtained by histological analysis of the cornea for Groups 1 and 2. Several studies in vitro reported the absence of significant differences in histological and immunohistochemical aspects ${ }^{(13-14)}$. However, this paper shows that the integration of the AM into the corneal epithelium was not affected by the type of preservation method used.

Ultrastructural analysis by TEM demonstrated a better preservation of the corneal epithelial basement membrane and desmosomes in corneas covered with freeze-dried AM than in those covered with cryopreserved AM. This structure plays an important role in the corneal epithelial adhesion and migration $^{(12)}$.

In conclusion, the freeze-drying method appears to be a good option for preserving human amniotic membranes to be used in ocular surface reconstruction. This method facilitates storage and transportation, reducing costs. It may increase the use of $\mathrm{AM}$ in surgical procedures, especially in developing countries.

\section{ACKNOWLEDGMENTS}

The authors thank Patricia Milenez, Andre Aguilera, Marcia Tanekai and Isabel dos Santos for assistance in the histological and ultrastructural process and analysis.

\section{RESUMO}

Objetivo: Avaliar a eficácia da liofilização da membrana amniótica (MA) para a reconstrução da superfície ocular em coelhos. Métodos: A liofilização é processo de preservação que mantém a MA estável durante longo tempo mesmo em temperatura ambiente. A córnea de um olho de cada coelho macho da raça Nova Zelândia foi marcada e desepitelizada. Essa área desepitelizada foi coberta com: Grupo 1: MA criopreservada (n=6); Grupo 2: MA liofilizada $(n=6)$ e Grupo 3: Não coberta $(n=3)$. A MA nos grupos 1 e 2 e a periferia da córnea no grupo 3 foram suturadas com nylon 10-0. A avaliação clínica foi realizada por um observador cego em relação à hiperemia, neovascularização e edema de córnea e reepitelização nos dia 1,7 e 30 pós-operatórios. Após o dia 30 os ratos foram eutanizados e suas córneas enviadas para análise histopatológica e ultra-estrutural. Resultados: Dois olhos no grupo 2 foram excluídos da análise devido à infecção. Não foi encontrada diferença estatisticamente significante entre os grupos em relação à avaliação clínica. Na microscopia eletrônica de transmissão, a membrana basal nos grupos de MA liofilizada e controle foi mais contínua e homogênea em relação ao grupo da MA criopreservada. Conclusões: O processo de liofilização parece ser boa opção para a preservação da membrana amniótica humana para utilização na reconstrução da superfície ocular.

Descritores: Amnio/transplante; Liofilização; Criopreservação; Procedimentos cirúrgicos reconstrutivos; Preservação de tecido/métodos; Coelhos

\section{REFERENCES}

1. van Herendael BJ, Oberti C, Brosens I. Microanatomy of the human amniotic membranes. A light microscopic, transmission, and scanning electron microscopic study. Am J Obstet Gynecol. 1978;131(8):872-80.

2. De Roth A. Plastic repair of conjunctival defects with fetal membrane. Arch Ophthalmol. 1940;23:522-5.

3. Kim JC, Tseng SC. Transplantation of preserved human amniotic membrane for surface reconstruction in severely damaged rabbit corneas. Cornea. 1995;14(5):473-84.

4. Santos MS, Gomes JA, Hofling-Lima AL, Rizzo LV, Romano AC, Belfort R Jr. Survival analysis of conjunctival limbal grafts and amniotic membrane transplantation in eyes with total limbal stem cell deficiency. Am J Ophthalmol. 2005; 140(2):223-30.

5. Gomes JA, Romano A, Santos MS, Dua HS. Amniotic membrane use in ophthalmology. Curr Opin Ophthalmol. 2005;16(4):233-40. Review.

6. Dua HS, Gomes JA, King AJ, Maharajan VS. The amniotic membrane in ophthalmology. Surv Ophthalmol. 2004;49(1):51-77. Review.

7. Gomes JA, Santos MS, Ventura AS, Donato WB, Cunha MC, Höfling-Lima AL. Amniotic membrane with living related corneal limbal/conjunctival allograft for ocular surface reconstruction in Stevens-Johnson syndrome. Arch Ophthalmol. 2003;121(10):1369-74.

8. Gomes JA, dos Santos MS, Cunha MC, Mascaro VL, Barros Jde N, de Sousa LB. Amniotic membrane transplantation for partial and total limbal stem cell deficiency secondary to chemical burn. Ophthalmology. 2003;110(3):466-73.

9. Tsubota K, Satake Y, Ohyama M, Toda I, Takano Y, Ono M, et al. Surgical reconstruction of the ocular surface in advanced ocular cicatricial pemphigoid and Stevens-Johnson syndrome. Am J Ophthalmol. 1996;122(1):38-52.

10. Shimazaki J, Yang HY, Tsubota K. Amniotic membrane transplantation for ocular surface reconstruction in patients with chemical and thermal burns. Ophthalmology. 1997;104(12):2068-76. Comment in: Ophthalmology. 2000;107(3):411-2.

11. Tseng SC, Prabhasawat P, Barton K, Gray T, Meller D. Amniotic membrane transplantation with or without limbal allografts for corneal surface reconstruction in patients with limbal stem cell deficiency. Arch Ophthalmol. 1998;116(4):431-41.

12. Hao Y, Ma DH, Hwang DG, Kim WS, Zhang F. Identification of antiangiogenic and antiinflammatory proteins in human amniotic membrane. Cornea. 2000; 19(3):348-52.

13. Kim JS, Kim JC, Na BK, Jeong JM, Song CY. Amniotic membrane patching promotes healing and inhibits proteinase activity on wound healing following acute corneal alkali burn. Exp Eye Res. 2000;70(3):329-37.

14. Visuthikosol V, Somna R, Nitiyanant P, Navikarn T. The preparation of lyophylised of fetal membrane for biological dressing. J Med Assoc Thai. 1992; 75(Suppl 1):52-9.

15. Nakamura T, Yoshitani M, Rigby H, Fullwood NJ, Ito W, Inatomi T, et al. Sterilized, freeze-dried amniotic membrane: a useful substrate for ocular surface reconstruction. Invest Ophthalmol Vis Sci. 2004;45(1):93-9.

16. Nakamura T, Inatomi T, Sekiyama E, Ang LP, Yokoi N, Kinoshita S. Novel clinical application of sterilized, freeze-dried amniotic membrane to treat patients with pterygium. Acta Ophthalmol Scand. 2006;84(3):401-5.

17. BenEzra D. Criteria for grading severity of clinical symptoms and signs. In: BenEzra D. Ocular surface inflammation. Guidelines for diagnosis and treatment. Panama: Highlights of Ophthalmology; 2003. p.30-2.

18. Srinivas S, Mavrikakis E, Jenkins C. Amniotic membrane transplantation for painful bullous keratopathy. Eur J Ophthalmol. 2007;17(1):7-10.

19. Saw VP, Minassian D, Dart JK, Ramsay A, Henderson H, Poniatowski S, Warwick RM, Cabral S; Amniotic Membrane Tissue User Group (AMTUG). Amniotic membrane transplantation for ocular disease: a review of the first 233 cases from the UK user group. Br J Ophthalmol. 2007;91(8):1042-7. 